\title{
Annual Report for 1973
}

At the end of the year membership stood at 3357, compared with 3229 in 1972 continuing the pattern of small increase over previous years; of the 350 new members elected 149 were overseas. There were 43 deaths and 179 resignations or deletions. A further 17 people took out benefactor membership and three new life members were elected.

\section{Oryx $100 \%$ Fund}

Donations totalling $£ 6867$ were received during the year, of which $£ 4704$ was earmarked. This was the second year of the arrangement whereby all unearmarked donations (to a total of $£ 5000$ ) are matched by the Society, and accordingly a further $£ 1704$ was so designated. $£ 9351$ was paid out to the twenty-seven projects listed in the audited account of the Fund on page 501. Grants went to help conservation in Costa Rica, Czechoslovakia, the Falkland Islands, the Galapagos Islands, Greece, India, Jordan, Kenya, Malaysia, the Mascarene Islands, Mozambique, Nepal, Nigeria, Rwanda, Sarawak, South Africa, Spain and Sudan, aiding, among other endangered animals, tiger, Arabian oryx, mountain gorilla, great Indian rhino, marine turtles and Asiatic lion. Among types of projects funded were surveys of species in their natural environment, the provision of much needed conservation education material and the support of national parks, especially in their anti-poaching activities.

The large item relating to the Falkland Islands represents an earmarked transfer payment from the Society on behalf of the Society for the Promotion of Nature Reserves for the purchase of Saddle, Ship, Cliffknob, Beef, North and Coffin islands and a part of New Island known as Landsend Bluff, which are now held by the SPNR. The FPS advises the SPNR on the management of these islands.

\section{Endangered Species Fund}

Three grants were made in 1973: $£ 200$ to Friends of the Earth, towards the cost of their very effective advertisement (illustrated by our Chairman) at the time of the International Whaling Commission meeting; $£ 67.18$ to the Survival Service Commission of IUCN, to enable Professor Tom Harrisson to attend one of its Alert Group meetings; and $£ 24.45$ to $\mathrm{Mr} \mathrm{A}$. Baxter Cooper for survey work in connection with the survival of the North Ronaldsay sheep in the Orkneys, work now taken over by the Rare Breeds Survival Trust.

\section{Legacies and donations}

Further instalments amounting to $£ 2750$ were received from the late Mrs Grace Soward, and other legacies were $£ 2500$ from the late Captain J. J. Toller, $£ 482$ from the late Mrs S. E. Elworthy, $£ 400$ from the late Edwin Cohen, $£ 100$ from the late F. L. Reynolds and $£ 25$ from the late John T. E. Kenney. Generous donations included $£ 200$ from the St Katherine's Fund and $£ 100$ from the Offenheim Charitable Trust and the second of three promised anonymous 
annual grants of $£ 2000$. A donation of $£ 100$ was received in memory of B. L. Thurber and $£ 325$ from Mrs E. Greville-Williams as a result of a bequest.

\section{Arabian Oryx Herd}

The Arabian oryx herd at Phoenix Zoo, Arizona, and San Diego Zoo, California, increased during the year from 34 to $38: 19$ male and 19 female, of which eight males and seven females, belong to the FPS. During the year six calves were born. Of the 38 animals, 31 are at Phoenix and seven at San Diego.

\section{Wildlife Tours}

There were no departures during the year but, under arrangement with a new agency, Peregrine Holidays of Oxford, tours to Rwanda and Zaïre and to Zambia and Botswana are planned for 1974, and to Sri Lanka (Ceylon) and South India for 1975. FPS members have been enabled to participate in a now fully-booked tour to the Galapagos Islands and upper Amazon basin in Ecuador leaving in August 1974, and further departures are being arranged. Both the Rwanda-Zairre and Ceylon-India tours have been planned by the Hon. Secretary and Editor in recent special visits to the countries concerned.

\section{International Meetings}

In February the Hon. Secretary represented both FPS and IUCN at the Plenipotentiary Conference to conclude an International Convention on Trade in Certain Species of Wildlife, held at Washington, DC. In June he represented the Society at the 25th International Whaling Commission meeting in London. The Hon. Secretary and Editor attended the 3rd WWF Conference held in Bonn in October and, immediately following this, the Survival Service Commission meeting in Morges. The Hon. Secretary also attended three meetings of the recently formed Alert Group of SSC, in London in January, Morges in May and Paris, in September. In the gap between the departure of Miss M. Warland as Executive Officer of the SSC and the appointment of Mr A. J. Mence in August, the Hon. Secretary visited Morges three times to help the Secretariat prepare the Alert Group agendas, and on one of those occasions attended the IUCN/WWF Joint Project Operation meeting.

\section{Representation on Other Bodies}

The Society has official representation as follows: The Chairman and Sir Landsborough Thomson on the Council for Nature; the Hon. Secretary at the International Whaling Commission as an observer, and on the Conservation Liaison Committee and the Council for Nature's Endangered Species Subcommittee; the Hon. Secretary and Captain C. R. S. Pitman on the Countryside Assembly; the Hon. Secretary and Dr J. D. Lockie on the Mammals Committee (formerly the Working Party on Mammalian Predator Control); the Hon. Secretary and Lt-Col. C. L. Boyle on the International Council for Bird Preservation, British Section; Lt.-Col. Boyle on the 
Oil Pollution Advisory Committee; Lord Medway on the Federation of Zoological Gardens of Great Britain and Ireland; Captain Pitman on the Rare Breeds Survival Trust; Major W. N. Scott on the Biological Council; Dr Robin Banerjee on the Assam Valley Wildlife Scheme and $\mathrm{Mr}$ Ian MacPhail as an observer on the Movement for Survival. During the year the Editor became the Society's representative on the Survival Service Commission of IUCN. In addition, Council members provide cross-representation on a further twenty-four bodies.

\section{Meetings of the Society}

A full house of more than 250 members and friends attended the Annual General Meeting on June 13th, at which the Society was addressed by Lord Greenwood and the BBC films The High Andes, Falls of Iguazu and Patagonia were shown after an introduction by Jeffery Boswall. A wine and cheese supper was served, as at the other meetings during the year, each of which filled the Zoo Meeting Rooms to capacity. In March Anthony Smith spoke on the Matto Grosso, followed by The Peace Game, a film generously placed on permanent loan with the FPS film library by the South African Tourist Corporation. The October meeting, at which Philip Wayre and Richard Waller spoke about tigers and the wildlife of India and Philip Wayre showed his film, Twilight of the Tiger, proved so popular (with 150 members having to be turned away) that a repeat programme the following month, made possible through the kindness of the two speakers, almost filled the hall for a second time.

\section{Film Library}

178 bookings were made in the year, a drop on last year probably explained by the superannuation of several well-used films, as the average number of showings-eight per film over the year-was the same as 1972. Three new films were purchased towards the end of the year: the BBC Horizon Whales, Dolphins and Men, the National Film Board of Canada's wolf film, Death of a Legend, and the National Film Board of South Africa's Blesbok.

\section{Christmas Cards}

62,745 Christmas cards were sold, the highest number ever. For this we have to thank Ralph Thompson, for allowing us to use his delightful portrait of a tiger cub, and Denys Ovenden for his picture of hedgehogs, which repeated the success of his badger two years ago. We are extremely grateful to both artists for their generosity.

\section{The Zoological Society of London}

The Society is, as always, most grateful to the Zoological Society of London and its staff for providing our office accommodation and for all kindness and facilities offered during the year. 


\section{The Auditors' Report}

To: The Council and Members

of the Fauna Preservation Society

Accounts for the year ended 31st December 1973

We have completed the audit of the books and accounts of the Society for the year ended 31st December 1973 and report thereon as follows:

\section{Life Membership Fund}

The balance standing to the credit of the Fund is now $£ 11,777$. This is after crediting $£ 450$ in respect of Life Membership Subscriptions received during the year and transferring $£ 215$ to the General Reserve Account which represents the value of subscriptions of those life members whose memberships ceased during the year.

\section{Film Purchases-Reserve Fund}

A transfer from Income and Expenditure account of $£ 364.99$ was added to the opening balance $£ 889.30$ and from this total of $£ 1,254.29$ was deducted purchases of $£ 383.63$. The balance to be carried forward is $£ 870.66$.

\section{Endangered Species Fund}

The balance at 1st January 1973 was

to which has been added from Income and Expenditure Account

Expenditure during the year was leaving a balance to be carried forward

$\begin{array}{r}719.42 \\ \hline 1,431.16 \\ 291.63 \\ \hline £ 1,139.53 \\ \hline\end{array}$

General Reserve Account

The balance on this fund at 1st January was

to which has been added:

Profit on sale of investment

$£ 20,305.55$

Legacies

Fees of deceased life members

Re-invested income

Surplus from Income and Expenditure Account

giving a balance at the year end of

743.11

$6,257.98$

215.00

$1,602.49$

237.24

\section{Investments}

The total investments at 31st December, 1973, at cost amounted to $£ 38,227$ and the market value at that date was $£ 40,728$, showing a net appreciation of $£ 2,501$.

\section{Surplus}

The surplus of assets over liabilities at the end of the year amounted to $£ 43,148.56$ compared with $£ 33,448.59$ at the end of the previous year.

Oryx $100 \%$ Fund

To the balance at 1 st January 1973 of $£ 5,146.98$ has been added $£ 3,697.30$ transferred from Income and Expenditure Account and £7,380.02 from Donations and Interest, making a total of $£ 16,224.30$. Grants amounting to $£ 9,351.12$ have been made during the year, leaving a balance of f6,873.18.

25th March, 1974 


\section{ORYX 100\% FUND}

\section{Year ending 31st December, 1973}

Balance at 1st January 1973

INCOME

Income for year-

Donations

Transfer from General Fund

Loan interest

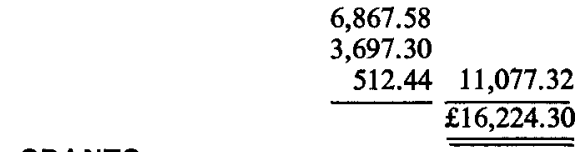

GRANTS

Purchase of islands, Falkland Islands (Society for the Promotion of Nature Reserves)

$2,500.00$

607.00

Conservation Education in Costa Rica (Director, Costa Rica National Parks Service)

500.82

500.57

500.00

Dugong Study, Kenya (R. B. Kater and A. G. Hillier)

500.00

Sudan (Lord Macpherson)

406.00

350.00

Lake Nakuru, Kenya (WWF)

Re-introduction of Arabian Oryx into Jordan (Wayne Homan)

Arabian Oryx Bibliography (Frank Turkowski)

327.14

280.87

Rewards for informers on rhino poaching, Nepal (John Blower)

251.14

Birds of Prey Conservation Programme, Western Spain (Director, Biological Station of Donaña)

251.05

Trengganu Leathery Turtle Project, Malaysia (Director of Fisheries, Trengganu State)

250.57

SANCCOB Rescue Station, South Africa (South African National Foundation for the Conservation of Coastal Birds)

Great Indian Rhino Study, Nepal (S. C. Michell)

Radio, Aberdare National Park, Kenya (East African Wild Life Society)

Binoculars for India (WWF Indian Appeal)

Study of Endangered Antelopes, Lebombos Mountains, Mozambique (Jose L. Tello)

Anti-poaching work, Mountain National Parks, Kenya (EAWLS)

Anti-poaching work, Tsavo East, Kenya (EAWLS)

Environment study, Skiathos Island, Greece (Environmental Survey-Greece)

Green Turtle replanting scheme, Sarawak (Curator, Sarawak Museum)

Giant Tortoise Feeding Behaviour Study, Galapagos

(Cambridge and London Galapagos Expedition 1973)

BOU Mascarene Islands Expedition (British Ornithologists' Union)

Black Vulture Ecology Study, Majorca (Dr J. D. Lockie)

Red Data Books to Czechoslovakia (Dr F. J. Turcek, Slovak Academy of Sciences) 
BALANCE SHEET

\begin{tabular}{|c|c|c|c|}
\hline \multirow{3}{*}{$\begin{array}{c}1972 \\
\stackrel{£}{6} \\
668\end{array}$} & \multicolumn{2}{|l|}{ LIABILITIES } & \multirow{3}{*}{$\underset{2,793.04}{\mathfrak{f}} \mathbf{p}$} \\
\hline & Sundry Creditors and Provisions & & \\
\hline & Receipts in Advance & & \\
\hline 619 & Subscriptions & & 738.53 \\
\hline 134 & Others & & - \\
\hline \multirow{6}{*}{$\overline{1,421}$} & & & $\overline{3,531.57}$ \\
\hline & $\begin{array}{l}\text { Balance, being excess of assets over liabilities: } \\
\text { Life Membership Fund }\end{array}$ & & \\
\hline & Balance at 1st January 1973 & $11,542.00$ & \\
\hline & Add: Fees received during year & 450.00 & \\
\hline & & $\overline{11,992.00}$ & \\
\hline & $\begin{array}{l}\text { Deduct: Transfer to General Reserve } \\
\text { Account: }\end{array}$ & & \\
\hline \multirow[t]{6}{*}{11,542} & Fees of deceased Life Members & 215.00 & $11,777.00$ \\
\hline & Film Purchases-Reserve Fund & & \\
\hline & Balance at 1st January 1973 & 889.30 & \\
\hline & Add: Transfer from Income and & & \\
\hline & Expenditure Account & 364.99 & \\
\hline & & $1,254.29$ & \\
\hline \multirow[t]{6}{*}{889} & Deduct: Purchases during year & 383.63 & 870.66 \\
\hline & Endangered Species Fund & & \\
\hline & Balance at 1st January 1973 & 711.74 & \\
\hline & Add: Transfer from Income and & & \\
\hline & Expenditure Account & 719.42 & \\
\hline & & $1,431.16$ & \\
\hline \multirow[t]{9}{*}{712} & Deduct: Expenditure during year & 291.63 & $1,139.53$ \\
\hline & General Reserve Fund & & \\
\hline & Balance at 1st January 1973 & $20,305.55$ & \\
\hline & Add: Profit on sale of investment & 743.11 & \\
\hline & $\begin{array}{l}\text { Legacies received during year } \\
\text { Transfer from Life Membership }\end{array}$ & $6,257.98$ & \\
\hline & Fund & 215.00 & \\
\hline & Re-invested income on Hume & & \\
\hline & Holdings Ltd. & $1,602.49$ & \\
\hline & Excess of Income over Expenditure & 23724 & 2036127 \\
\hline 34,870 & Wui tide yeal & & $f 46,680.13$ \\
\hline
\end{tabular}


-31st DECEMBER, 1973

\begin{tabular}{|c|c|c|c|c|}
\hline \multirow{2}{*}{$\begin{array}{l}1972 \\
£\end{array}$} & \multicolumn{4}{|c|}{ ASSETS } \\
\hline & & $\begin{array}{l}\text { Sundry Debtors and Payments in } \\
\text { Advance }\end{array}$ & & \\
\hline & 309 & Income tax recoverable on investments & 242.11 & \\
\hline 2,094 & 1,785 & Other & $2,929.20$ & $3,171.31$ \\
\hline 1,383 & & $\begin{array}{l}\text { Stocks in Hand } \\
\quad \text { (at or under cost) }\end{array}$ & & $1,405.00$ \\
\hline & & Office Furniture and Fixtures (not & & \\
\hline - & & valued) & & - \\
\hline & & $\begin{array}{l}\text { Investments (at cost) } \\
907 \text { Guardian Roval Exchange }\end{array}$ & & \\
\hline & & $\begin{array}{l}\text { Assurance Co. Ltd. } 25 \text { p ordinary } \\
\text { shares }\end{array}$ & $1,788.25$ & \\
\hline & & $\begin{array}{l}400 \text { Metal Box Co. Ltd. } £ 1 \\
\text { ordinary shares } \\
1,125 \text { Pearl Assurance Co. Ltd. } 5 p\end{array}$ & 850.00 & \\
\hline & & ordinary shares & 962.45 & \\
\hline & & $\begin{array}{l}£ 10,000 \text { Hume Holdings Ltd. Loan } \\
\text { 525 Thorn Electrical Industries }\end{array}$ & $10,000.00$ & \\
\hline & & $\begin{array}{l}\text { Ordinary 25p shares } \\
3,045 \text { United Biscuit (Holdings) }\end{array}$ & $2,233.90$ & \\
\hline & & $\begin{array}{l}\text { Ordinary } 25 p \text { shares } \\
f 4,136.00 \text { Greater London } 9 \frac{1}{4} \%\end{array}$ & $2,263.46$ & \\
\hline & & 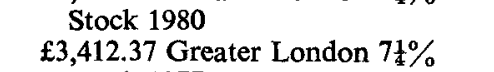 & $4,120.22$ & \\
\hline & & $\begin{array}{l}\text { Stock } 1977 \\
\text { 1,050 Viking Resources Trust Ltd. }\end{array}$ & $3,274.94$ & \\
\hline & & $\begin{array}{l}\text { 25p shares } \\
1,400 \text { General Electric Co. Ltd. }\end{array}$ & $1,299.68$ & \\
\hline & & $\begin{array}{l}\text { 25p shares } \\
\text { 1,736 Standard Bank Ltd. } £ 1\end{array}$ & $1,990.43$ & \\
\hline & & ordinary shares & $2,635.50$ & \\
\hline 30,340 & & Deposits with local authorities & $6,808.18$ & $38,227,01$ \\
\hline 1,053 & & Balance at bank and cash in hand & & 387681 \\
\hline 34,870 & & & & $\mathfrak{f 4 6 , 6 8 0 . 1 3}$ \\
\hline
\end{tabular}

We have examined the above Balance Sheet and accompanying Income and Expenditure Account, and the Receipts and Payments Account relating to the Oryx $100 \%$ Fund, with the books and accounts of the Society and with the information and explanations supplied and certify them to be in accordance therewith. We have verified the bank balance and the investments of various funds.

Knightway House, 20 Soho Square, NORTON KEEN \& CO. London W1V 6QJ Chartered Accountants 


\section{INCOME AND EXPENDITURE ACCOUNT}

GENERAL PURPOSES

1972

f

5,32

300

376

673

215

2,125

475

Rent of offices-
Regent's Park

Less: Donation from Zoological Society

521 Office and miscellaneous expenses

701 Stationery

359 Telephone

92 Advertising

577 Postage

38 Films-insurance

120 Accountancy and audit

45 Income tax-accountancy charges (including prior years)

305 Grants and subscriptions to other bodies

2,632 Transfer to $100 \%$ Fund

1,000 Transfer to Endangered Species Fund

38 Office furniture and fittings

16 Conference expenses

Balance-excess of income over expenditure

680 carried to Balance Sheet

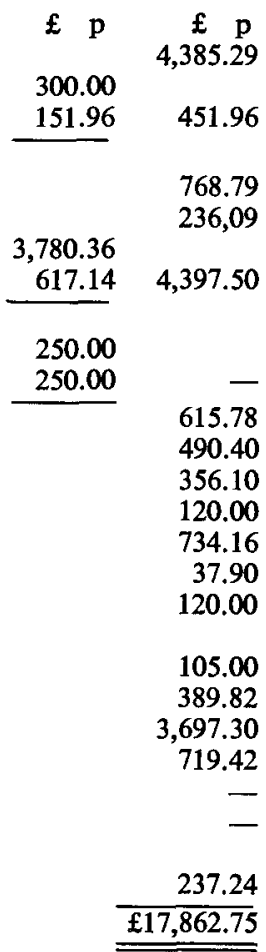




\section{for the year ended 31st DECEMBER, 1973}

\section{ACCOUNT}

\begin{tabular}{|c|c|c|c|c|}
\hline 1972 & & INCOME & & \\
\hline $\mathfrak{f}$ & $\mathfrak{f}$ & Subscrintions-_ & $£ \quad p$ & $£$ \\
\hline & 8,457 & Current & $8,740.90$ & \\
\hline 9,473 & 1,016 & Tax recovered on Covenants $1972 / 73$ & $1,046.77$ & $9,787.67$ \\
\hline 4,381 & & Donations & & $4,398.71$ \\
\hline 1,238 & & Interest on Investments (Gross) & & $1,316.47$ \\
\hline 778 & & Journals-sales and advertisements & & 777.56 \\
\hline & 1,615 & $\begin{array}{l}\text { Christmas Cards-sales } \\
\text { Less: Cost of production and post- }\end{array}$ & $2,500.00$ & \\
\hline 422 & 1,193 & age & $1,297.60$ & $1,202.40$ \\
\hline 319 & & Sundry sales-net & & 379.94 \\
\hline & & $\begin{array}{l}\text { Films-handling charges-net income } \\
\text { Less: Transferred to Film }\end{array}$ & 364.99 & \\
\hline & & Purchases Reserve Fund & 364.99 & - \\
\hline
\end{tabular}

